\title{
Intolerably high risk in ascending aortic surgery
}

\author{
Giovanni Battista Luciani, MD
}

\author{
From the Division of Cardiac Surgery, Department of Surgery, Dentistry, Pediatrics and Gynecology, University \\ of Verona, Verona, Italy. \\ Disclosures: Author has nothing to disclose with regard to commercial support. \\ Received for publication June 13, 2018; revisions received June 13, 2018; accepted for publication June 14, 2018; \\ available ahead of print Aug 8, 2018. \\ Address for reprints: Giovanni Battista Luciani, MD, Division of Cardiac Surgery, Department of Surgery, \\ Dentistry, Pediatrics and Gynecology, University of Verona, O. C. M. Piazzale Stefani 1, Verona 37126, Italy \\ (E-mail: giovanni.luciani@univr.it). \\ J Thorac Cardiovasc Surg 2018;156:e187-8 \\ $0022-5223 / \$ 36.00$ \\ Copyright (C 2018 by The American Association for Thoracic Surgery \\ https://doi.org/10.1016/j.jtcvs.2018.06.044
}

In this issue of the Journal, Ruge and associates ${ }^{1}$ report on an entirely catheter-based management of prosthetic aortic valve dysfunction and ascending aortic pseudoaneurysm. By combining aortic valve-in-valve replacement and custom-made covered stent graft repair of the ascending aorta, Ruge and associates ${ }^{1}$ were successful in treating a 73-year-old patient with ambulation problems. Although thoracic endovascular aortic repair has since become the mainstay treatment for most descending thoracic aortic disease conditions, ${ }^{2}$ endovascular management of ascending aortic pathology thus far has been restricted to select clinical series or, more commonly, anecdotal reports. ${ }^{3-6}$ The reasons explaining limited resort to endovascular repair are inherent with the peculiar anatomic features of the ascending aorta, including collateral arteries (coronary, brachiocephalic) and discrepancy in ventral versus dorsal curvature of the vessel, requiring customized design of the graft. Similar to other off-label therapies, endovascular ascending aortic repair has been reserved to high-risk patients, justifying, at least in part, the disappointing outcomes found in larger series and reviews. ${ }^{3-5}$ Indeed, hospital mortality rates as high as $18 \%$ and cerebrovascular accident rates up to $14 \%$ are not unusual. Furthermore, average follow-up observations rarely exceed 12 to 18 months, casting additional doubts on the stability of endovascular repair, particularly in younger individuals.

Whereas complete endovascular treatment of ascending aortic and aortic valve pathology has been reported before in elderly, high-risk patients with acute dissection, ${ }^{7}$ in the present report Ruge and associates chose to extend this strategy to an elective patient with ascending aortic false aneurysm due to sternal wire fracture. The rationale to offer an endovascular management in an elderly patient with impaired ambulation was to avoid a reportedly intolerable risk associated with the open surgical approach. Undoubtedly, rehabilitation after an uncomplicated endovascular procedure can be expected to be shorter than after open aortic repair. Yet, the statement that standard surgical repair of an ascending aortic pseudoaneurysm poses an

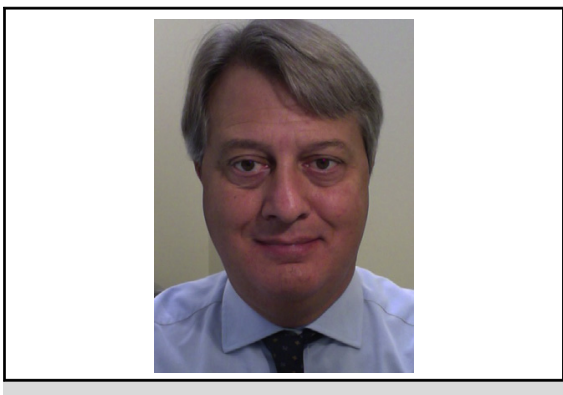

Giovanni Battista Luciani, MD

Central Message

The strategy to keep risk of complex ascending aortic surgery tolerable is to refer elective patients to experienced cardiac units.

See Article page e183.

"intolerable" risk to the patient begs the question of which risk has become "tolerable" in aortic surgery nowadays.

In fact, outcomes after open repair of ascending aortic false aneurysms are satisfactory, ranging from a $10 \%$ hospital mortality in smaller cardiac units ${ }^{8}$ to $6 \%$ in large referral aortic surgery units. ${ }^{9}$ These results compare favorably to the existing reports on endovascular repair of ascending aortic pseudoaneurysms, which report hospital mortality as high as $14 \%$ and non-negligible treatment failures leading to conversion to open surgical repair. ${ }^{10}$ Clearly, open surgical repair using peripheral arterial cannulation, moderate or deep hypothermic bypass, and a period of (often very limited) circulatory arrest to access the chest may be qualified as a more "invasive" procedure. Certainly, it is more time-consuming for the surgeon, but the evidence available suggests it is less risky for the patient and associated with a more favorable late outlook. Complex aortic surgery, particularly reoperative, is not the only domain in structural heart disease where the issue of "risk averting" is starting to surface. Perhaps the most notable operation suffering from this condition is the Ross procedure. Pulmonary autograft aortic valve replacement is a strategy associated with unsurpassed early and late results in children and young adults in dedicated cardiac units. ${ }^{11}$ However, it is perceived as more hazardous because it is more technically challenging. ${ }^{12}$ Although fostering innovation in catheter-based strategies to deal with demanding structural cardiovascular disorders, our community needs to jealously preserve its surgical armamentarium, which remains far more successful both early and late in low-risk 
and intermediate-risk patients. Perhaps the only way to contrast the trend toward "risk averting" in complex cardiac surgery is to encourage physicians to direct elective patients to dedicated regional referral cardiac units.

\section{References}

1. Ruge H, Herold U, Lange R. Stent-graft treatment of an ascending aortic false aneurysm after surgical aortic valve replacement. J Thorac Cardiovasc Surg. 2018;156:e183-5.

2. Fattori R, Montgomery D, Lovato L, Kische S, Di Eusanio M, Ince H, et al. Survival after endovascular therapy in patients with type B aortic dissection: a report from the international registry of acute aortic dissection (IRAD). JACC Cardiovasc Interv. 2013;6:876-82.

3. Roselli EE, Idrees J, Greenberg RK, Johnston DR, Lytle BW. Endovascular stent grafting for ascending aorta repair in high-risk patients. J Thorac Cardiovasc Surg. 2015;149:144-51.

4. Muetterties C, Menon R, Wheatley G. Ascending TEVAR: a systematic review of isolated endovascular repair of the ascending aorta. J Vasc Surg. 2016;63:152S-3S.

5. Bernardes RC, Navarro TP, Reis FR, Lima LC, Monteiro EL, Procopio RJ, et al. Early experience with off-the-shelf endografts using a zone 0 proximal landing site to treat the ascending aorta and arch. J Thorac Cardiovasc Surg. 2014; 148:105-12.

6. Tsilimparis N, Debus ES, Oderich GS, Haulon S, Terp KA, Roeder B, et al. International experience with endovascular therapy of the ascending aorta with a dedicated endograft. J Vasc Surg. 2016;63: 1476-82.

7. Wilbring M, Ghazy T, Matschke K, Kappert U. Complete endovascular treatment of acute proximal ascending aortic dissection and combined aortic valve pathology. J Thorac Cardiovasc Surg. 2015;149:e59-60.

8. Katsumata T, Moorjani N, Vaccari G, Westaby S. Mediastinal false aneurysm after thoracic aortic surgery. Ann Thorac Surg. 2000;70:547-52.

9. Atik FA, Navia JL, Svensson LG, Vega PR, Feng J, Brizzio ME, et al. Surgical treatment of pseudoaneurysm of the thoracic aorta. J Thorac Cardiovasc Surg. 2006;132:379-85.

10. Preventza O, Henry MJ, Cheong BY, Coselli JS. Endovascular repair of the ascending aorta: when and how to implement the current technology. Ann Thorac Surg. 2014;97:1555-60.

11. Sharabiani MT, Dorobantu DM, Mahani AS, Turner M, Peter Tometzki AJ, Angelini GD, et al. Aortic valve replacement and the ross operation in children and young adults. J Am Coll Cardiol. 2016;67:2858-70.

12. Treasure T, Hasan A, Yacoub M. Is there a risk in avoiding risk for younger patients with aortic valve disease? BMJ. 2011;342:d2466. 